\title{
4. Engaging Bodies as Matters of Care
}

\author{
Counting and Accounting for Death During Migration
}

Amade M'charek and Julia Black'

\begin{abstract}
This chapter attends to the often-neglected bodies of migrants who do not make it to their destination alive. It addresses initiatives where the bodies are attended to at the population level, i.e. practices of counting, as well as at the individual level, i.e. the burial, registration and potential forensic identification of individual deceased bodies. We introduce the notion 'matters of care' to analyse modes of knowing. We argue that caring for these bodies with dignity and respect - through counting, listing and mapping the dead as well as through attempts at identifying the individual bodies - produces proximity with the dead and accountability for deadly border management regimes.
\end{abstract}

Keywords: body management, DNA profiling, missing, families, representation

Narratives of migration 'crises' are pervasive but problematic: the high numbers of people seeking refuge from situations of war, violence and poverty have been referred to as 'tsunamis' and 'floods' of migrants. This rendering not only dehumanizes people on the move, but it also produces distances between us versus them and here versus there. While numbers about those who migrate to Western countries dominate the media and policy documents, those who do

1 We are grateful to the editors, Paolo Cuttitta and especially Tamara Last for generous feedback and guidance. We also thank all participants of the workshop 'Dead Bodies': Andonea Jon Dickson, Catriona Jarvis and Syd Bolton, Anna O'Leary, Gabriella Soto, Claire Moon and Alessandra La Vaccara for their contributions to the discussion during the conference. Amade M'charek thanks the European Research Council (ERC) for supporting her research through an ERC Consolidator Grant (fp7-617451-RaceFaceid-Race Matter: On the Absent Presence of Race in Forensic Identification).

Cuttitta, P. \& Last, T. Border Deaths: Causes, dynamics and consequences of migration-related mortality. Amsterdam: Amsterdam University Press, 2020.

DOI: 10.5117/9789463722322_CHO4 
not make it to their destination alive do not seem to merit much attention. As Last and Spijkerboer (2014) have argued, the paucity of proper documentation of deaths during migration has led to a lack of accountability on behalf of politicians. The more than 30,000 fatalities documented by the International Organization for Migration (IOM 2018) in the last five years - likely a gross undercount of the true number - testify to the failure of border management regimes worldwide, a 'governing of migration through death' (Squire 2017).

Across the world, particularly during crises in which many hundreds, if not thousands, die in a short period of time, migrant bodies have a real, tangible presence. Moreover, these bodies are often found in irregular spaces. For instance, they are recovered by the nets of Libyan fishermen, called in by tourists on the beaches of Spain and Turkey, and discovered - sometimes long after decomposition - by crew in the stowage of ships and by ranchers in the desert between the US and Mexico. Those bodies not found are interred in deserts, seas and rivers across the world.

In this chapter, we attend to the often-neglected bodies of those who do not make it to their destination alive. We do so by addressing initiatives where the bodies are cared for at the individual level, i.e. the burial, registration and identification of individual bodies. Introducing the notion of 'matters of care' (Puig de la Bella Casa 2011), we argue that caring for these bodies with dignity and respect - through attempts at identifying the individual bodies - produces proximity with the dead and accountability for deadly border management regimes.

Addressing migrant deaths as 'matters of care' can help us address humanitarian issues simultaneously as political issues. Issues such as accounting for migrant bodies are not infrequently related to colonial legacies, postcolonial conditions as well as militarized borders (see Chapter 6). Approaching migrant bodies as matters of care thus helps us not to reproduce separations between worlds (the proverbial 'the West and the rest') and to underline their entangled nature. Moreover, how we deal with the dead is one of the attributes distinguishing humans from other animals. Thus caring for the dead is one way to maintain our humanity amidst the human dramas that are so easily clustered under the heading 'crisis'. Finally, and closer to the practice of managing and identifying dead bodies, caring is not merely about an affective relation, but also about a mode of knowing. Caring as a mode of knowing is methodologically open-ended and works with the contingencies found on the ground, rather than (idealized) laboratory settings (Puig de la Bella Casa 2011).

Caring as a mode of knowing and relating in practice is simultaneously a mode of accounting. Engaging the bodies of dead migrants is, first of all, taking care of these bodies as human remains, remains that belong to specific 
individuals whose identities can be uncovered. Secondly, given the manner and quantities of death, engaging these bodies implies accounting for the origins of and reasons of these dramas, reasons such as deadly border management regimes (see Chapter 1). Thirdly, taking care of bodies also entails their representation in numbers. Accounting - to stay closer to its etymology of counting - is then about the affective qualities of numbers and their representations.

In what follows we will address only two modes of accounting. We will start with the visualization of numbers of death, and their affective qualities, and then discuss the issue of management and identification of bodies.

\section{Attending to numbers as a mode of accounting for deaths}

Numbers are key actors in debates and policy about migration as well as in accounting for migrant bodies. While in the case of living migrants, numbers have often been accompanied by words such as 'floods,' 'waves' or 'tsunamis,' as if to indicate a life-threatening situation, attempts to count migrant bodies often come by themselves, without further classification. In this way, numbers objectify, produce a distance and may even trivialize what they represent (see Chapters 2 and 3 ). Yet we contend that counting is in fact a crucial and important practice of care and of accounting.

Through counting a record is made bearing witness to the dead, and the way numbers are represented can encourage the audience to care about the dead (Sontag 2003). Thus, while counting is an important bureaucratic procedure it may also produce a relation of care.

The production of numbers is key to state policy, lending to statistics, stemming from 'state' (Desrosières 2002). It is thus an important step for policymaking in general and might, in the case of migrant death, produce an incentive for states to act, and produce an obligation to prevent deaths (see Chapter 8). But does the measuring of death also produce accountability? Do numbers produce an affective response with a wider public, a proximity to those who lost their lives and a responsibility for 'our' policies? We want to suggest that numbers are, potentially, capable of such a response. To be sure, the kind of response depends both on the subjective disposition of the addressee and the way numbers are presented.

Migrant bodies and their numbers are predominantly represented through maps or lists. Here we present an image for each of the two categories. Figure 4.1 is a map from the IOM's Missing Migrants Project (MMP); Figure 4.2 is a screenshot from UNITED for Intercultural Action's 'List of Deaths'. The MMP began publishing its database in 2014 and is the only initiative aimed 
at regularly documenting deaths in the process of international migration worldwide. The List of Deaths is an ongoing initiative that since 1993 has documented 34,361 'deaths related to Fortress Europe' from a variety of sources, including primarily media and NGO reports but also, in the latest update, incidents recorded in the MMP database (UNITED 2018). ${ }^{2}$

\section{Figure 4.1 IOM's Missing Migrants Project homepage}

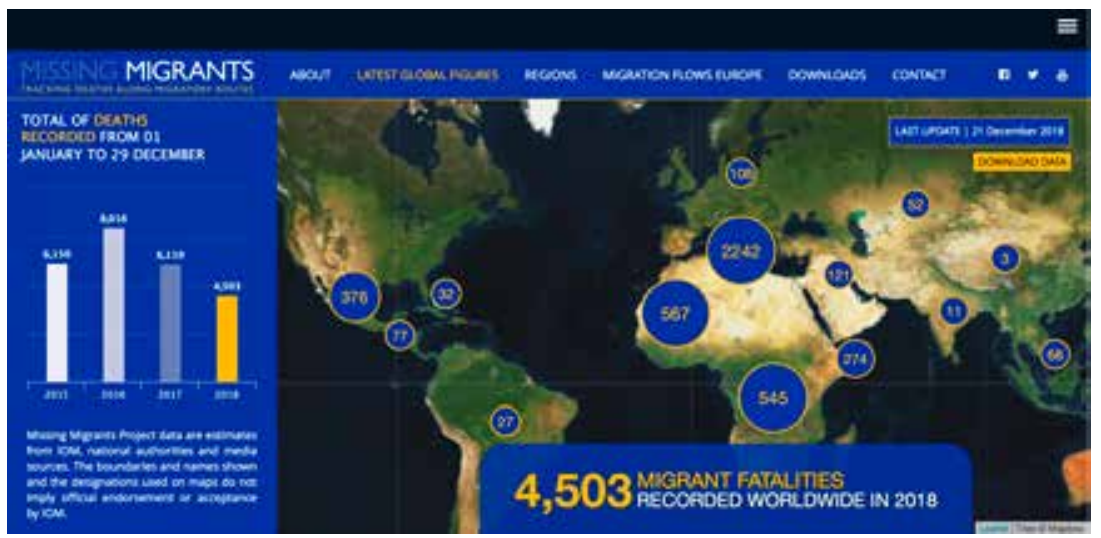

Source: http://missingmigrants.iom.int

The landing page of the MMP website (Figure 4.1) represents the numbers of recorded deaths and disappearances during migration over the past four years - encapsulating both documented bodies and an estimation of those migrants who are lost and presumed dead. But it does more: it disaggregates the numbers, not only by visually representing them through bars that compare the numbers of migrant bodies across years, it also situates the dramas in specific regions on a physical map, thereby demarcating certain political borders. Smaller and larger bulbs visualize the proportions. By clicking on the bulbs, the map zooms in and visualizes the breakdown of the numbers and the places of the incidents in the relevant region. By further clicking on the flagged locations, the map provides detailed information for each incident (number of dead and missing, sex, country of origin, cause of death, location, information source, etc.). In sum, the MMP map goes beyond the mere presentation of numbers, providing a human and geographical context which allows the public to identify with the dead and the missing. Thus, it represents what we call an affective geography. 3

2 For a discussion of sources of border death data see Chapter 2.

3 We borrow the definition from Giaccardi and Fogli (2008) with a caveat: While these authors theorize affective geography as a means of both visualizing and eliciting affective meaning 
The List of Deaths (Figure 4.2) might, at first glance, produce a distance. It lists 34,361 deaths since 1993 according to date found, name, gender and age, region found, cause of death, etc. Once downloaded as a PDF, however, the list is immediately overwhelming: even such an unadorned list demonstrates the sheer quantity of deaths related only to migrants' deaths in Europe. Reading the information it records is even more arresting: 'died off coast of Tripoli after Libyan coast guard banned NGO ships from approaching', 'electrocuted when he climbed on roof of freight train in depot outside Thessaloniki', 'strangled by desperate mother who hanged herself afterwards in Eckolstädt asylum centre'. The name column emphasizes the hundreds of unidentified bodies and the limitations of border death data. It invites the viewer to explore and interpret the data in their own way, but forces viewers to engage directly with morbid details. Reading these, it is hard to maintain distance from the suffering and hardships.

\section{Figure 4.2 UNITED's List of Deaths}

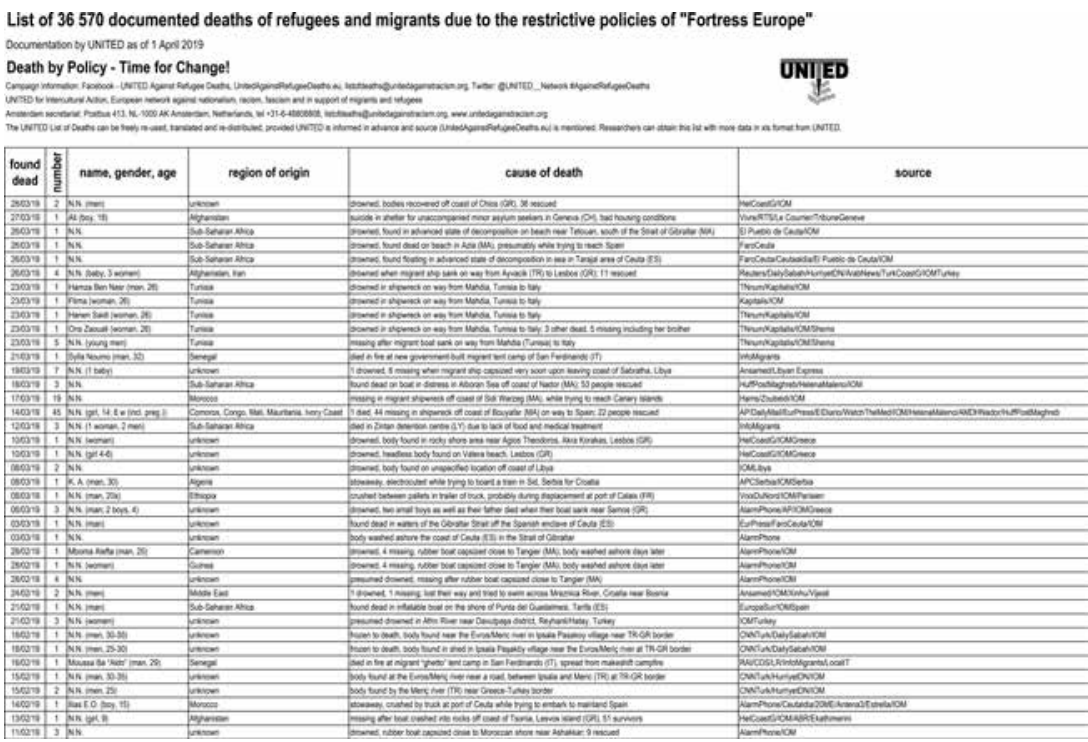

Source: http://unitedagainstrefugeedeaths.eu/about-the-campaign/ about-the-united-list-of-deaths/

("We have defined affective geographies as web maps that reveal how we are "affected" by environmental settings, and that in turn "affect" the way in which we experience and interpret the environmental setting mapped'), we use this term to define mapping methods aimed just at eliciting affective meaning. 
Both maps and lists, we argue, may produce affective responses, moving the viewer to situate the bodies beyond their numerical representation. The bodies and their counts in the above examples do not only represent death, but also evoke narratives about lives envisioned and dreams crushed, or journeys taken and hardship encountered. In this way the dead bodies become matters of care for they initiate a response in the viewer. Moreover, the above examples make clear that counting may well go hand in hand with accounting, in the sense that they make visible the scale and details of migrant deaths and migrant bodies. Numbers are capable of producing a profound proximity and of doing the political work of accountability (see Chapter 8). To be sure, as we indicated at the very beginning of this chapter, the use of numbers does not always produce proximity (see Chapter 3). Numbers couched in a dull policy report and stripped of any context will lose their affective power. Data on mortality in humanitarian emergencies generally, sometimes produce political interest or attract aid to a crisis; however, such an intervention is not guaranteed, and has not prevented further deaths (Checchi and Roberts 2005). Whether numbers produce proximity to the problem of migrant death, or distance, whether they produce accountability or indifference is dependent on the form in which they are presented, and the willingness of the viewer to engage and interact.

\section{Managing and identifying bodies as a mode of accounting}

Initiatives to count migrant deaths usually centre on incidents, and numbers are determined based on information other than the bodies found. The Deaths at the Borders Database is one of just a few body-based databases, as it is compiled from official death certificates (Last et al 2017). Another example is the Arizona OpenGIS Initiative for Deceased Migrants, a database which lists all migrant bodies found in Arizona through collaboration with the Pima County Office of the Medical Examiner and Humane Borders, Inc. (Humane Borders 2018). These datasets cannot capture the many migrant bodies that are not found. Instead, a body-based approach is typically adopted for identification procedures which are only triggered when a body is found (see Chapter 2).

The identification of bodies in the context of migration presents many challenges (see e.g. Olivieri et al 2018). The first challenge concerning identification is that bodies of those who died on route are difficult to identify as belonging to migrants. In many cases bodies may not be recovered 
until long after the time of death, if at all. For example, nearly one-third of the 2,999 migrant bodies recorded in Arizona since 2000 were skeletal remains (Arizona OpenGIS Initiative for Deceased Migrants 2018). This means that unless a person dies on a well-known migratory route, it is difficult to determine whether the body belongs to a migrant or not. This designation is important because without it, authorities may not be able to assist families who are searching for their loved ones who went missing during a transnational journey (see Chapter 5 ).

Secondly, it is difficult to clarify the identity of a migrant body based on documents or on visual identification (Tidball-Binz 2007). Those who migrate irregularly might do so without identifying documents or while carrying false documents or their identifying documents might get lost along the way. Similarly, in practice, visual identification by family members is difficult. ${ }^{4}$ First, because local forensic authorities and records are largely inaccessible for relatives, or because relatives face difficulties retrieving a visa to travel to the countries where their beloved ones might have been found. Second, when possible and based on viewing a relative's body or personal effects, identification can be unreliable due to the condition of the body, the lack of consistent retrieval and recovery of the deceased's belongings, not to mention the stress on the family. This means that the identity of victims can only be verified through verbal accounts of fellow travellers, personal effects, or DNA and other forensic matching techniques by comparison with existing records.

In the criminal justice system, particularly in the context of crime-solving, forensics has become a potent field, with powerful technologies such as fingerprint comparisons, DNA profiling, biometrics, etc. Equally, in the context of mass disasters, such as terrorist attacks, tsunamis or airplane crashes, particularly in cases involving many victims from the global North, disaster victim identification (DVI) protocols are well-developed. These protocols have spurred standardized DVI forensic methods to be used even under disheartening and hectic circumstances. Typical identification methods in DVI are dental records comparisons, identifying bodily markers such as specific scars, physical traumas, or tattoos, DNA comparisons or personal effects such as clothing (labels, etc).

Despite these well-established forensic practices, identifying the bodies of migrants is extremely difficult and requires additional 'infrastructural

4 For example, Central American migrants may use false documents identifying themselves as Mexican nationals, so that if they are apprehended by the United States Border Patrol, they would be deported back to Mexico rather than to their home country (Gill et al 2013). 
work' (M'charek 2018). For example, people who die in the desert will lose all characteristics within just a few days, rendering migrant bodies into skeletal remains, often highly dispersed by animals or weather conditions. Even though skeletal material is a good starting point for identification, without any additional information or personal effects it is extremely hard to individualize. Those who wash ashore after drifting in the water for long periods of time will be visually unrecognizable and, even if they arrive intact, will lose their fingerprints as the skin comes loose. Most profoundly, the usual DVI protocol, based on comparisons to medical or dental records, often loses relevance as it is very hard to determine the country of origin of a deceased migrant and, correspondingly, to find the relevant records (Olivieri et al 2018). Even DNA is of little help in identifying migrant bodies: unless there is an immediate family member to whom the profile of the deceased person can be compared, DNA will be of little help because of the lack of DNA reference populations ${ }^{5}$ from regions such as Sub-Saharan Africa or the Middle East (M'charek and Casartelli 2019). Next to survivors' accounts, ${ }^{6}$ the only chance of identification in such challenging, yet increasingly common cases will be when family members start to look for their relatives and inter alia submit their DNA to look for a possible match or recognize catalogued personal effects of their missing relative.

The International Committee of the Red Cross (ICRC) has developed several initiates to actively engage family members in the tracing of their missing or deceased relatives. Since 2013, the ICRC's Trace the Face programme allows those searching for missing relatives to upload a photo of themselves and describe the person they are looking for through their nearest Red Cross, Red Crescent or ICRC office. Since 2017, the Missing Migrants in the Mediterranean Transregional Pilot Project liaises, where possible, with families of missing migrants potentially affected by the shipwreck on 18 April 2015 off the coast of Libya which claimed approximately 800 lives. Most recently, the ICRC has carried out the Missing and Deceased Migrants Pilot Project, aimed at the collaboration of family members in South Africa and Zimbabwe (Singleton et al forthcoming).

5 In this case, 'reference population' refers to a group of DNA samples defined by geographic data which can aid in identifying the location of origin of the deceased.

6 Survivors can provide a useful starting point, but they are rarely consulted and information volunteered is often ignored or not transmitted to the relevant authorities (see Tsapopoulou et al 2012). The live bodies are separated from the dead bodies as soon as possible, after which they are managed by very different authorities and interact with different actors (Zagaria 2011, see also Chapter 1). 
Collecting ante mortem data for DNA matching requires access to family members of the deceased, who may not have the resources or mobility necessary, or might be hesitant to provide a DNA sample as they might fear repercussions from state authorities (Olivieri et al 2018; ICRC 2018a). Also, medical records may not be available in countries of origin, especially if the deceased were not economically well-off. Finally, the authorities of countries of origin may not be willing to collaborate and help in the collection of ante mortem data. Most states - countries of origin, transit and destination - lack programs for the reporting of persons missing abroad and none provide assistance to families who seek to travel to the potential site of death or burial of their lost loved ones. In Tunisia, under pressure of the relatives of young men who went missing since 2011 and the Tunisian Forum for Economic and Social Rights (FTDES), a governmental commission of inquiry was created in 2015 to help families find clues about the destiny of their children in Italy. This committee was, however, heavily critiqued for a lack of serious interest in the issue. ${ }^{7}$ Thus while state-led identification of migrant bodies is rare there are several NGOs and international governmental organizations working towards improving the situation.

One example can be found in Arizona, where the Pima County Office of the Medical Examiner (PCOME) has partnered with the NGO Colibrí Center for Human Rights to identify 65 per cent of migrant bodies since 2000 (PCOME 2018), one of the highest success rates reported. However, the PCOME covers only those migrant bodies recovered in Arizona, while identification of migrant bodies in the other three US states remains highly fragmented.

Less successful but nonetheless admirable is an investigation into the shipwreck of 3 October 2013 led by the Italian National Commission for Missing Persons, which identified 31 out of 53 missing persons sought by family members, all of whom resided in Europe (Robins forthcoming). However, those identified represent less than 10 per cent of the 366 individuals who died in the shipwreck (Olivieri et al 2018). More recently, the same Italian team has started forensic identification work on hundreds of deceased bodies who were trapped in the aforementioned shipwreck of 18 April 2015. While the remarkable infrastructure for boarding the ship, examining, documenting, sampling and burying the bodies was successful, the identification thereof will be largely dependent on the collection of ante

7 See e.g. https://www.alaraby.co.uk/english/indepth/2018/12/5/tunisian-familiespush-for-truth-over-missing-mediterranean-youth 
mortem samples (M'charek and Casartelli 2019). While both investigations are a step in the right direction, such a case-by-case approach represents only a small fraction of the thousands of migrants who have died in shipwrecks on the Central Mediterranean route in recent years.

A final important example is the Hellenic DNA database established in 2015 in Athens. This DNA database is precisely aimed at compiling a registry of deceased migrants in Greece in the hope of identifying them. It has compiled hundreds of profiles of deceased persons and of reference samples from relatives looking for beloved ones. Reports about the identification of migrant bodies have been made in several publications. ${ }^{8}$ The success of the DNA database should be viewed in the light of the Hellenic DVI, the first national DVI unit which is committed to dealing with migrant fatalities and ensuring that DNA samples are taken during autopsy and passed to the DNA laboratory. ${ }^{9}$

The initiatives described here generally take either a family-led or stateoriented approach. Only the Argentine Forensic Anthropology Teams' (EAAF) Border Project brings together both sets of actors, which has created a regional mechanism to exchange forensic identification on migrant bodies and missing persons across several Central American states (Doretti et al 2017).

Family-oriented initiatives are the approach most often used by non-state actors, likely due to issues of access (see Chapters 1,2 and 6). Such initiatives are emblematic of the care migrant bodies deserve: the involvement with those most affected by the death of a relative produces not only a better chance of identification but also profoundly affective stories from those dealing with 'ambiguous loss' (Ben Attia et al 2015; see Chapter 5). Globally, the ICRC and national Red Cross and Red Crescent Societies collaborate on the Restoring Family Links programme, which collects missing persons reports from families separated by conflict, disaster and migration (ICRC 2018a). The aforementioned Colibrí Center is based in Arizona, but has collected missing persons reports - including free DNA collection - from thousands of families from across the United States and Latin America. Their database contains more than 3,000 open missing persons cases, which are compared with the forensic records from the PCOME (Colibrí Center 2018). These and related initiatives have developed in varied contexts, where states did not

8 See e.g. https://www.unhcr.org/gr/en/2999-athens-dna-lab-helps-trace-those-lost-at-seaon-aegean-crossing.html

9 See e.g. https://gmdac.iom.int/sites/default/files/medmissing/dr._penelope_miniati_-_dna_ analysis_centralized_dna_database._useful_tools_in_identification_of.pdf 
adequately assume their responsibility to care for the bodies of deceased people, let alone to identify them. Related to the lack of comprehensive state initiatives to identify migrant bodies, there is hardly any coordination between states on this issue. Because migrant deaths are inherently transnational, international collaboration to link ante- and post-mortem data is required for the scientific identification of migrants (see Chapter 8).

One state-oriented approach to identification began recently in the European context. ${ }^{10}$ The International Commission on Missing Persons (ICMP), an intergovernmental organization, is conducting an assessment of state capacities to identify missing persons in Italy, Greece, Malta and Cyprus, which is aimed at a capacity-building and standardization programme for identification across European states bordering the Mediterranean, though it is notable that Spain is omitted. ${ }^{11}$ The project ultimately aims to build the capacities of states to manage bodies in the interest of identification, and to foster international data exchange through standard-setting. Given its longstanding experience with DVIs, the ICMP has expertise on how to protect the privacy of deceased persons and their relatives, a crucial component when dealing with migrant bodies and families who may fear retribution from states (see also ICRC 2018b). The ICMP's state-based approach, while in its infancy, is a crucial first step towards improving transnational coordination in the interest of the identification of migrant bodies.

While there is not space here to address the genealogies of these various initiatives in depth, they have not developed solely in laboratories or meeting rooms, but rather in a process of encountering deceased migrants and their families (see e.g. Kovras and Robins 2015). As the success of the EAAF's Border Project and the collaboration between the PCOME and Colibrí Center shows, any attempt to identify missing migrants must involve both states and families themselves - for both practical and moral reasons.

\section{Managing migrant bodies: a neglected form of care}

The identification of deceased migrants is contingent upon the management of bodies, including their recovery, storage, and burial. It is precisely here that the work of identification is usually halted. Studies focusing on the

10 Although this initiative is currently focused on Europe, there is an interest and hope that in the future it can also include Northern African Mediterranean countries.

11 See, https://www.icmp.int/press-releases/developing-a-joint-process-on-the-issue-ofmissing-migrants-in-the-mediterranean-region/ (accessed 14 June 2019). 
management of migrant bodies in the Mediterranean and US-Mexico border context indicate that current efforts are far from adequate (Ben Attia et al 2015; Last 2016; Ochoa O'Leary and Soto 2018).

Ideally, though this is far from reality, the process of managing bodies consists of three temporally ordered steps: recovery, storage and burial, leading ultimately to identification. ${ }^{12}$ Recovery does not only involve making all reasonable efforts to find bodies, but to retrieve the personal effects of the dead, and wherever possible, to interview eyewitnesses about the deceased person and the circumstances of their death (Ben Attia et al 2015). Storage consists of the storage of data, samples and personal effects. At this stage, an autopsy needs to be performed to determine the circumstances of death. The police and the public prosecutor need to exclude the possibility of a crime, in which case a criminal investigation is at issue. Storage implies the registration of the body and personal effects both verbally and by means of photography, by photographing the body and identifying markers (tattoos, scars, moles, etc), as well as clothing and other personal belongings. At this stage, biological samples are taken for future identification. The body receives a unique identification number, indicating, for instance, the date and location where the body was found, that should accompany the body, the samples and all data throughout subsequent stages (see e.g. Tapella et al 2016). Storage of bodies, data and personal effects needs to be organized in such a way that they are easily retrievable, identifiable and, ideally, in accordance with international standards such as those set out by the ICRC (2017). After examining the body and storing the data, a death certificate should be issued and the body buried.

In order to ensure the retrieval of bodily remains in case of post-burial identification, a unique identification code should be assigned to the body from its recovery, and used on all data retrieved from it, as well as the grave. For example in Europe, since 2016, there is an official process of identification used by EU countries around the Mediterranean Sea. Bodies receive a unique identifying number that starts with the telephone country code (in accordance with the Dublin Regulation to register migrants in the first country entered). While this official process is based on the management of bodies described above, in practice the situation is far from standardized and even where procedures do exist, they are not always followed. For

12 In practice the process is more erratic, see Introna, Di Vella , and Campobasso 2013; M'charek and Casartelli, forthcoming. 
example, Tapella et al (2016) show how, in the case of Sicily, due to the increased number of casualties, the bodies of dead migrants have been buried across municipalities, depending on where space was found. This fact, combined with irretrievable data about the deceased, has contributed to severe difficulties in locating the persons buried.

\section{Conclusion: caring for migrant bodies}

In this chapter, we have focussed on the neglected bodies of those who do not make it to their destinations alive. While these bodies have been attended to by attempts to count and measure the magnitude of migrant death, even less care and attention has been given to the proper management of these bodies or the identification thereof.

We have introduced the concept of 'matters of care' to call attention to the bodies of dead migrants. Attending to these bodies with care elicits novel ways of knowing and caring for the dead. Both mapping the magnitude of death and attempting to identify the dead bodies come with many challenges and require inventive methods (see M'charek and Casartelli 2019). While care relates to the moral obligation to view the dead as human beings (Moon 2018; Last Rights Project 2018), it is also about the material relation to grant them the right to not be forgotten. It is a way of attending to the principle stipulated by the Interpol General Assembly of 1996, namely, that 'human beings have the right not to lose their identities after death' (Resolution No. AGN/65/RES/13, preamble). The question is how to do that in practice where standard procedures do not work, or where a crisis (e.g. high number of casualties) is chronic.

To be sure, as this chapter makes clear, there has generally been little interest by state authorities to know the dead and to properly manage their bodies. Yet, internationally a variety of initiatives have been developed, mostly by NGOs, in which new ways of caring for the dead are emerging. These initiatives make clear that caring for the dead is a layered activity; it is an administrative practice, a forensic practice, an international collaborative practice, a humanitarian practice that involves both the dead and their relatives, as well as a political practice that attends to the rights of the dead but also aims at engaging us as witnesses. Counting, mapping, registering and burying make us accountable for those who die in search of a better life. They allow for the 're-membering' of those who die, as part of a human community. 


\section{References}

Ben Attia, Frida, Tara Brian, Adrian Carrasco Heiermann, Stefanie Grant, Catriona Jarvis, Iosif Kovras, Frank Laczko, Giorgia Mirto, Katerina Polychroni, Simon Robins, Ann Singleton, and Amal Shaiah. 2016. Missing Migrants in the Mediterranean: Addressing the Humanitarian Crisis. Summary Report. Mediterranean Missing Project. http://www.mediterraneanmissing.eu/wp-content/uploads/2015/10/ Mediterranean-Missing-Summary-report-290816.pdf (accessed 5 June 2019)

Checchi, Francesco and Les Roberts. 2005. Interpreting and Using Mortality Data in Humanitarian Emergencies. London: Humanitarian Practice Network. https:// odihpn.org/wp-content/uploads/2005/o9/networkpapero52.pdf(accessed 5June 2019)

Colibrí Center for Human Rights. 2018. 'About us.' http://www.colibricenter.org/ about-us/ (accessed 5 June 2019)

Desrosières, Alain. 2002. The Politics of Large Numbers. A History of Statistical Reasoning. Cambridge, MA: Harvard University Press.

Doretti, Mercedes, Carmen Osorno Solís and Rachel Daniell. 2018. 'The Border Project: Towards a Regional Forensic Mechanism for the Identification of Missing Migrants.' In: Fatal Journeys Volume 3, Part 1:Improving Data on Missing Migrants, edited by Frank Laczko, Ann Singleton and Julia Black, pp. 99-117. Geneva: International Organization for Migration. http://publications.iom.int/system/ files/pdf/fatal_journeys_volume_3_part_1.pdf (accessed 5 June 2019)

Giaccardi, Elisa and Daniela Fogli. 2008. 'Affective Geographies: Toward Richer Cartographic Semantics for the Geospatial Web.' In: Proceedings of the working conference on Advanced visual interfaces (AVI 'o8), pp. 173-180.

Gill, Nick, Deirdre Conlon, Imogen Tyler and Ceri Oeppen. 2013. 'The Tactics of Asylum and Irregular Migrant Support Groups: Disrupting Bodily, Technological, and Neoliberal Strategies of Control.' Annals of the Association of American Geographers 104 (2), 373-381.

Humane Borders. 2018. 'Arizona OpenGIS Initiative for Deceased Migrants.' http:// www.humaneborders.info/ (accessed 5 June 2019)

ICRC. 2018a. 'Missing and Deceased Migrants Pilot Project in South Africa and Zimbabwe: 2016 to 2018.' https://www.icrc.org/en/document/missing-anddeceased-migrants-pilot-project-south-africa-and-zimbabwe-2016-2018 (accessed 5 June 2019)

ICRC. 2018b. The Humanitarian Metadata Problem: 'Doing no harm' in the Digital Era. ICRC: Geneva. https://privacyinternational.org/report/2509/humanitarianmetadata-problem-doing-no-harm-digital-era (accessed 5 June 2019)

ICRC. 2017. 'Missing Migrants and Their Families: The ICRC's Recommendations to Policymakers.' ICRC Policy Paper 4325/002. https://www.icrc.org/en/publication/ 
missing-migrants-and-their-families-icrcs-recommendations-policy-makers (accessed 5 June 2019)

IOM. 2018. 'Methodology.' Missing Migrants Project. https://missingmigrants.iom. int/methodology (accessed 5 June 2019)

Introna, Francesco, Giancarlo Di Vella and Carlo Pietro Campobasso. 2013. 'Migrant Deaths and the Kater Radez I Wreck: From Recovery of the Relict to Marine Taphonomic Findings and Identification of the Victims.' International Journal of Legal Medicine 127, 871-879.

Kovras, Iosif, and Simon Robins. 2015. 'The Families of Missing Migrants and Refugees May Never Know Their Fates.' The Conversation (1 October 2015). http:// theconversation.com/the-families-of-missing-migrants-and-refugees-maynever-know-their-fates-48396 (accessed 12 July 2019)

Last Rights Project. 2018. Declaration for the Dignified Treatment of all Missing and Deceased Persons and their Families as a Consequence of Migrant Journeys (The Mytilini Declaration). https://www.lastrights.net/mytilini (accessed 5 June 2019) Last, Tamara, and Thomas Spijkerboer. 2014. 'Tracking Deaths in the Mediterranean.' In: Fatal Journeys Tracking Lives Lost during Migration, edited by Tara Brian and Frank Laczko, pp. 85-108. Geneva: International Organization for Migration (IOM).

Last, Tamara. 2016. 'Who Are Boat Migrants? Challenging the Anonymity of Death by Border Sea.' In: 'Boat Refugees' and Migrants at Sea: A Comprehensive Approach, edited by Violeta Moreno-Lax and Efthymios Papastavridis, pp. 79-116. Leiden: Brill.

M'charek, Amade. 2018. “'Dead-bodies-at-the-border”: Distributed Evidence and Emerging Forensic Infrastructure for Identification.' In: Bodies as Evidence: Security, Knowledge, and Power, edited by Mark Maguire, Ursula Rao, Nils Zurawski, pp. 89-110. Durham: Duke University Press.

M'charek, Amade, and Sara Casartelli. 2019. 'Identifying Dead Migrants: Forensic Care Work and Relational Citizenship', Citizenship Studies (published online 7 August 2019). https://doi.org/10.1080/13621025.2019.1651102.

Moon, Claire. 2018. 'Last Rights: The Human Rights of the Dead.' Paper for the conference 'Border deaths and migration policies: State and non-state approaches', Amsterdam, 14-15 June 2018.

O'Leary, Ochoa, and Gabriella Soto. 2018. 'When Death Comes Knocking: Documenting Efforts to Identify and Enumerate the Dead Along the U.S. Mexico Border.' Paper for the conference 'Border deaths and migration policies: State and non-state approaches', Amsterdam, 14-15 June 2018.

Olivieri, Laura, Debora Mazzarelli, Barbara Bertoglio, Danilo De Angelis, Carlo Previderè, Pierangela Grignani, Annalisa Cappella, Silvano Presciuttini, Caterina Bertuglia, Paola Di Simone, Nicolò Polizzi, Agata Iadicicco, Vittorio Piscitelli 
and Cristina Cattaneo. 2018. 'Challenges in the Identification of Dead Migrants in the Mediterranean: The Case Study of the Lampedusa Shipwreck of October 3rd 2013.' Forensic Science International 285, 121-128.

Pima County. Office of the Medical Examiner. 2018. Annual Report 2017. https:/ webcms.pima.gov/UserFiles/Servers/Server_6/File/Government/Medical\%20 Examiner/Resources/Annual-Report-2017.pdf

Puig de la Bellacasa, Maria. 2011. 'Matters of Care in Technoscience: Assembling Neglected Things.' Social Studies of Science 4 (1), 85-106.

Robins, Simon. Forthcoming. Analysis of Best Practices in the Identification of Missing Migrants: Implications for the Central Mediterranean. Geneva: International Organization for Migration.

Singleton, Ann, Frank Laczko and Julia Black. Forthcoming. Fatal Journeys Volume 4: Missing migrant children. Geneva: International Organization for Migration.

Sontag, Susan. 2003. Regarding the Pain of Others. New York, NY: Farrar, Straus and Giroux.

Squire, Vicki. 2017. 'Governing Migration Through Death in Europe and the US: Identification, Burial and the Crisis of Modern Humanism.' European Journal of International Relations 23 (3), 513-532.

Tapella, Amelie, Giorgia Mirto, and Tamara Last. 2016. 'Deaths at the Borders. From Institutional Carelessness to Private Concern. Research Notes From Italy.' Intrasformazione: Rivista di Storia delle Idee 5 (1), 57-64.

Tidball-Binz, Morris. 2007. 'Managing the Dead in Catastrophes: Guiding Principles and Practical Recommendations for First Responders.' Geneva: ICRC. https:// www.icrc.org/en/international-review/article/managing-dead-catastrophesguiding-principles-and-practical (accessed 5 June 2019)

Tsapopoulou, Katerina, Marianna Tzeferakou and Salinia Stroux. 2012. Walls of Shame. Accounts from the Inside: The Detention Centres of Evros. PRO ASYL Foundation: Frankfurt. https://www.proasyl.de/en/material/walls-of-shameaccounts-from-the-inside-the-detention-centres-of-evros/ (accessed 12 July 2019)

UNHCR. 2018. 'Mediterranean Situation. Operational Portal Refugee Situations.' https://data2.unhcr.org/en/situations/mediterranean (accessed 5 June 2019)

UNHCR Regional Office for South-East Asia. 2015. 'Irregular Maritime Movements in South-East Asia 2014.' https://storybuilder.jumpstart.ge/en/unhcr-imm\#3 (accessed 5 June 2019)

UNITED for Intercultural Action. 2018. 'List of 34,361 documented deaths of refugees and migrants due to the restrictive policies of "Fortress Europe".' (last updated 5 May 2018). http://unitedagainstrefugeedeaths.eu/about-the-campaign/aboutthe-united-list-of-deaths/ (accessed 5 June 2019) 
Zagaria, Valentina. 2011. Grave Situations: The Biopolitics and Memory of the Tombs of Unknown Migrants in the Agrigento Province. Unpublished MA dissertation, London School of Economics.

\section{About the authors}

Amade M'charek is Professor of Anthropology of Science at the department of Anthropology, University of Amsterdam. Her research interests are in forensics, forensic anthropology and race in the criminal justice and the humanitarian setting. M'charek is the Principal Investigator of the ERCConsolidator Project RaceFaceID on forensic identification, face and race.

Julia Black coordinates the Missing Migrants Project for IOM's Global Migration Data Analysis Centre in Berlin. She is a co-editor of IOM's global report series on migrant deaths and identification, Fatal Journeys, and has authored several other publications on the topic. 
